EESTI NSV TEADUSTE AKADEEMIA TOIMETISED. 29. KOIDE FOUSIKA * MATEMAATIKA, 1980, NR. 2

ИЗВЕСТИЯ АКАДЕМИИ НАУК ЭСТОНСКОЙ ССР. ТОМ 29 ФИЗИКА * МАТЕМАТИКА, 1980, № 2

\title{
TIME-RESOLVED COHERENT ANTI-STOKES RAMAN SCATTERING BY A SINGLE SYNCHRONOUSLY PUMPED MODE-LOCKED CW DYE LASER
}

\author{
(Presented by K. K. Rebane)
}

Synchronously pumped mode-locked CW dye laser with an additional etalon in the ravity is capable of multi-frequency operation, i.e. mode locking is achievable on several etalon lines simultaneously. Jitter-free components of different wavelengths of the multi-frequency pulse make such laser a promising tool in coherent four-photon timeresolved spectroscopy.

The abilities of synchronously pumped oxazine laser in multi-frequency operation in coherent anti-Stokes Raman scattering (CARS) spectroscopy are investigated on the sample of liquid nitrogen.

\section{Introduction}

During the last decade CARS has proved a powerful tool in studying vibrational resonances in various media. High intensity and good spatial properties as well as better spectral resolution and selectivity of Ramanactive modes have made CARS a tool that enables one to resolve problems out of reach of conventional Raman spectroscopy (for details see $\left.\left[{ }^{1-4}\right]\right)$. The introduction of picosecond pulses to four-photon spectroscopy has made it possible to study vibrational relaxation processes (both $T_{1}$ and $T_{2}$ ) directly in the time domain $\left[{ }^{4,5}\right]$. Besides, the advantages of $\mathrm{CW}$ lasers over the pulsed ones are well known by steady CARS. Consequently, the application of synchronously pumped mode-locked * CW (SP ML CW) dye lasers would be of great importance in the progress of relaxation-time measurements as the moderate peak power, stability and high repetition rate of the pulses avoid undesirable by-effects and allow an essential improvement of detection accuracy.

Yet there are very few papers devoted to time-resolved four-photon spectroscopy with SP ML CW dye lasers. This is probably due to difficulties in synchronizing the pulses at different wavelengths requisite for picosecond pump and probe technique. To solve the problem J. P. Heritage et al. used synchronous pumping of two independent dye lasers by an actively mode-locked argon laser, but they could not get rid of the jitter of independent pulses $\left[{ }^{6}\right]$. Recently a method of producing multi-frequency pulses free of jitter from a single SP ML CW dye laser was proposed $\left[{ }^{7}\right]$. This enables one to build a decay-time measurement system based on one SP ML CW dye laser, which greatly simplifies the equipment along with good time resolution.

\footnotetext{
* Passively mode-locked CW dye lasers are not easily synchronizable.
} 
In what follows we describe the principles of such a set-up, then give the experimental details, and present the preliminary results of the test experiments on liquid nitrogen.

\section{Method}

In steady CARS resonant excitation of the vibration runs at the difference frequency of two input beams. $\left(\omega_{v i b}=\omega_{1}-\omega_{2}\right)$ and usually the anti-Stokes scattering of the blue component is being monitored $\left(\omega_{\text {sign }}=\right.$ $\left.=2 \omega_{1}-\omega_{2}\right)$. Therefore two lasers will suffice.

For picosecond transient CARS one needs a fast excitation of the vibration (i. e. at least one of the excitation pulses should be of picosecond duration) and a probing picosecond pulse $\left(\omega_{3}\right)$.

For the signal to lie in the anti-Stokes region one has to use a probing pulse with $\omega_{3}>\omega_{2}$. A conventional SP $M L C W$ dye laser system consists of a ML ion laser (pulse duration, $\sim 100$ ps is too long for probing) and a dye laser (pulse duration $\sim 1-8 \mathrm{ps}$ ). Making use of the system for pico-CARS experiments, we operated the dye laser so as to produce two-frequency picopulses in a single cavity (Fig. 1) $\left[{ }^{7}\right]$. The above-mentioned operation was achieved by specially selected spectral filters in the cavity. The equal widths of both auto- and crosscorrelation functions reveal no jitter between the spectral components of the pulse, whereas the use of a single dye laser (as well as the pump laser) greatly simplifies the set-up required for transient CARS spectroscopy.*:

After spectral separation of the pulses, the coherent vibrations were excited by one of the components $\left(\omega_{D 1}\right)$ together with the pump laser pulse at $\omega_{1}$ (excitation occurs only during the overlapping time of the pulses). The second component $\omega_{D 2}$ (the blue one) was used to monitor the vibrations yielding anti-Stokes signal at $\omega_{s i g n}=\omega_{1}-\omega_{D 1}+\omega_{D 2}$.

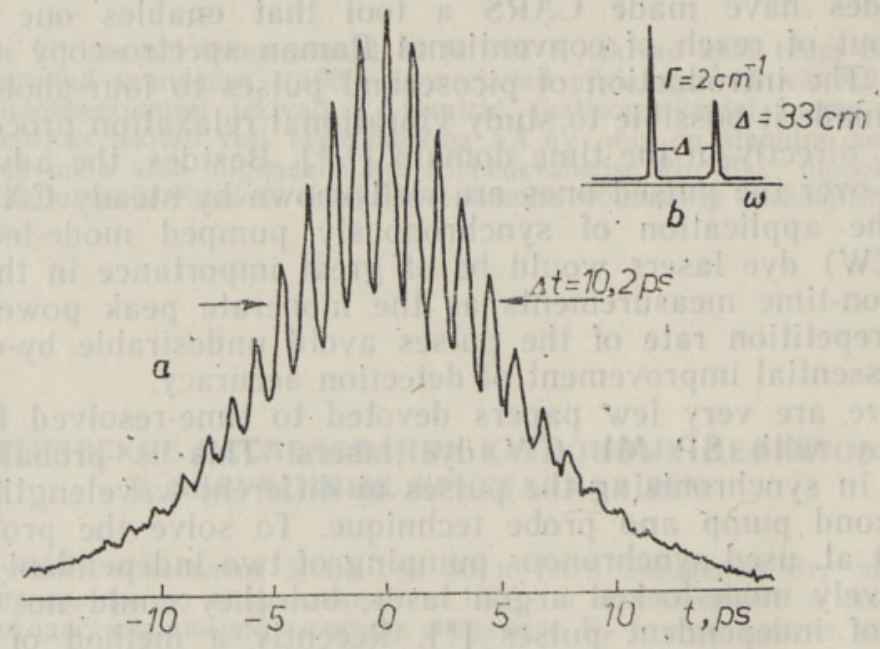

Fig. 1. Autocorrelation function of the twofrequency pulse $(a)$ and the corresponding spectrum

(b). Pulse duration $\sim 6$ ps.

** The use of a single cavity automatically meets the requirements for identical threshold and equivalent mechanical conditions for different frequencies (cf. [ $\left.{ }^{6}\right]$ ). 
Picosecond duration and high stability of the pulses should considerably enhance the accuracy of the measurement.

\section{Experimental set-up}

Spectra-Physics oxazine-1 dye laser (model 375) pumped by acoustooptically mode-locked $\mathrm{Kr}^{+}$laser (model 171) was used (see Fig. 2). The ML pump laser beam (average power $\sim 1 \mathrm{~W}$ ) was divided by means of a 1200 grooves per $\mathrm{mm}$ grating (DG 1). The zeroth-order reflection was used as the dye laser pump and the first-order reflection was directed to the sample $\left(\omega_{1}\right)$. The second-order beam was used for monitoring the pulse shape by a fast photodiode (PD, model 403) and a sampling scope (SS, total risetime $<200 \mathrm{ps}$ ). The grating allowed the plasma lines to be filtered out. When studying a small CARS signal, this is of firstrate importance. To detect the duration of the pump pulse ( $80-90 \mathrm{ps})$ a synchroscan streak camera (SC $\left[{ }^{8,9}\right]$ ) was used. The wavelength tuning and two-frequency operation was carried out using the main tuning wedge (W) and a fine tuning etalon (FP). The dye laser pulse duration $\sim 6 \mathrm{ps}$ and the difference between the frequencies $\left(\omega_{D 2}-\omega_{D 1}=33 \mathrm{~cm}^{-1}\right)$ were etalon limited. The last relation implies that the signal appears only at $33 \mathrm{~cm}^{-1}$ to the violet from $\mathrm{Kr}^{+}$line, which unfortunately is unfavourable for detection because of high stray-light level at this frequency.

The two-frequency output of the dye laser was resolved by another grating (DG2) and directed into the channels of the pump (red component, $\left.\omega_{D 1}\right)$ and the probe (blue component, $\omega_{D 2}$ ). Both channels contained

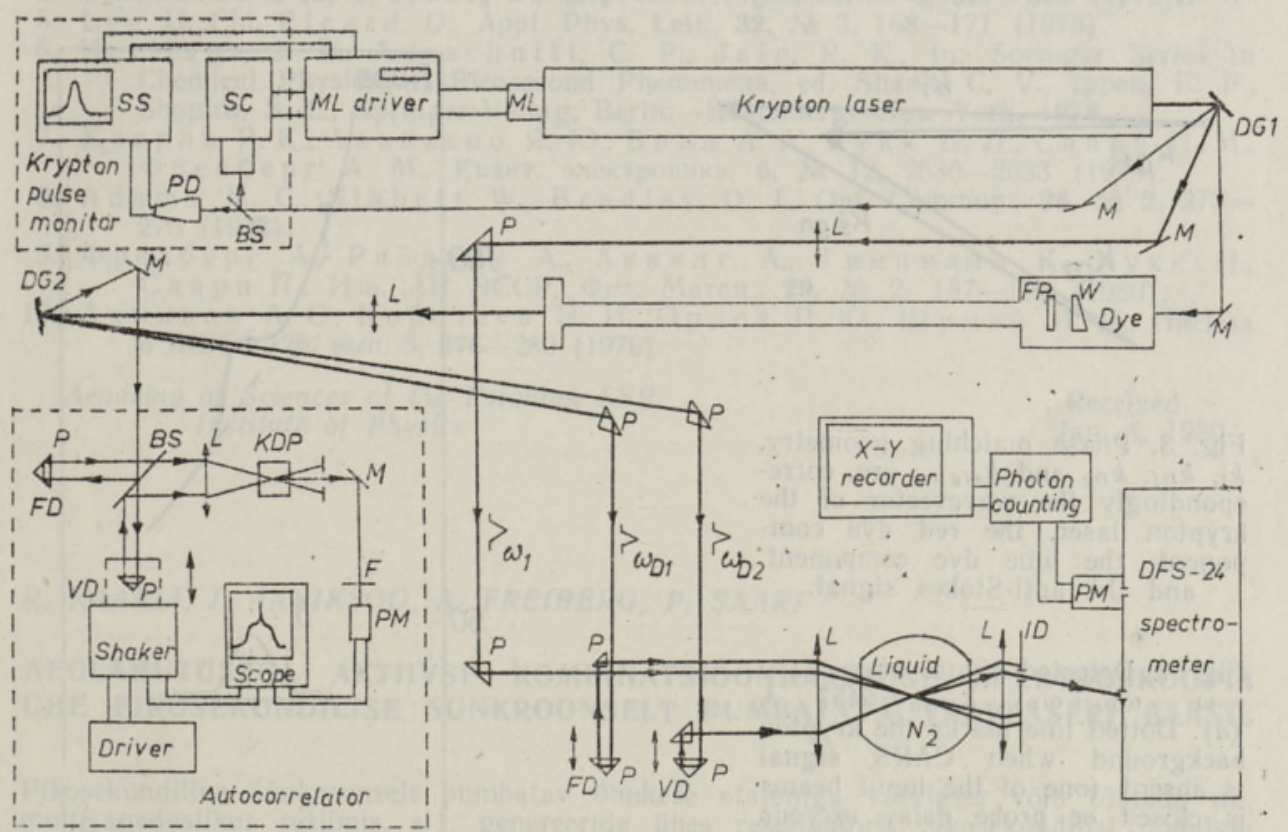

Fig. 2. Experimental set-up. $M L$ - mode locker, $\mathrm{W}$ - main tuning wedge, FP - fine tuning etalon, DG1 and DG2 - diffraction gratings, BS - beamsplitter, PD photodiod, SS - sampling scope, SC - synchroscan streak camera, M - mirror, P prism, L - lens, VD and FD - variable and fixed delays, respectively, PM photomultiplier tube. 
delay lines (FD, VD) to ensure a proper time overlapping.*** The resultant collinear beams were focused into the sample by means of a 6-cm-focal-length lens. Temporal and spatial overlapping of the pulses were optimized using sum-frequency generation in a $\mathrm{LiO}_{3}$ crystal.

The signal beam was spatially filtered and fed into a DFS-24 spectrometer equipped with a conventional photon-counting system. In order to test the set-up, first the anti-Stokes signal at $\omega^{\prime}$ sign $=2 \omega_{1}-\omega_{D 1}$ was monitored.

\section{Results}

To demonstrate the possibilities of the set-up, liquid nitrogen - well-known for its CARS properties from several investigations $\left[{ }^{1}\right]$ - was used as a model system. Comparatively long phase relaxation time $(\sim 70 \mathrm{ps})$ of the strong $\omega_{\text {vibr }}=2326.5 \mathrm{~cm}^{-1}$ vibration is very suitable for testing the equipment.

To meet the phase matching conditions we used a $2^{\circ}$ angle between the pump beams, which has proved optimal in steady CARS experiments $\left[{ }^{10}\right]$. The probe beam was set at $\sim 24^{\circ}$ with respect to the pump beams that yielded the signal at $2^{\circ}$ to the probe beam (see Fig. 3 ).

The average power of the pump and probe beams in the sample was accordingly $300 \mathrm{~mW}$ (peak power $\sim 30 \mathrm{~W}$ ) at $\omega_{1}, 3 \mathrm{~mW}(\sim 4 \mathrm{~W})$ at $\omega_{D 1}$ and $7 \mathrm{~mW}(\sim 10 \mathrm{~W})$ at $\omega_{D 2}$. The CARS signal at $\omega_{s i g n}^{\prime}=2 \omega_{1}-\omega_{D 1}$ was $25 \cdot 10^{4}$ pulses per second (not corrected for the monochromator losses and phototube efficiency). Certain efficiency losses of the antiStokes scattering must appear at $\omega_{\text {sign }}=\omega_{1}-\omega_{D 1}+\omega_{D 2}$, as there occur changes in the probe power and spatial overlapping of the pulses.

We observed the CARS signal at zero delay at $\omega_{\text {sign }}=15488 \mathrm{~cm}^{-1}$ (Fig. 4). The signal intensity $(\sim 10$ pulses per second $)$ was lower than

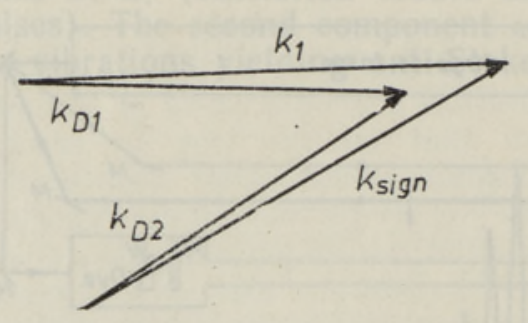

Fig. 3. Phase matching geometry. $k_{1}, k_{D 1}, k_{D_{2}}$ and $k_{s i g n}$ are, correspondingly the wavevector of the krypton laser, the red dye component, the blue dye component, and the anti-Stokes signal.

Fig. 4. Detected signal at $\omega_{\text {sig } n}=$ $=\omega_{1}-\omega_{D_{1}}+\omega_{D_{2}} \quad \lambda_{\text {sig }}=6457 \AA$ (a). Dotted line marks the krypton background when CARS signal is absent (one of the input beams is closed or probe delay exceeds $\sim 100$ ps). Signal after background substraction (b).

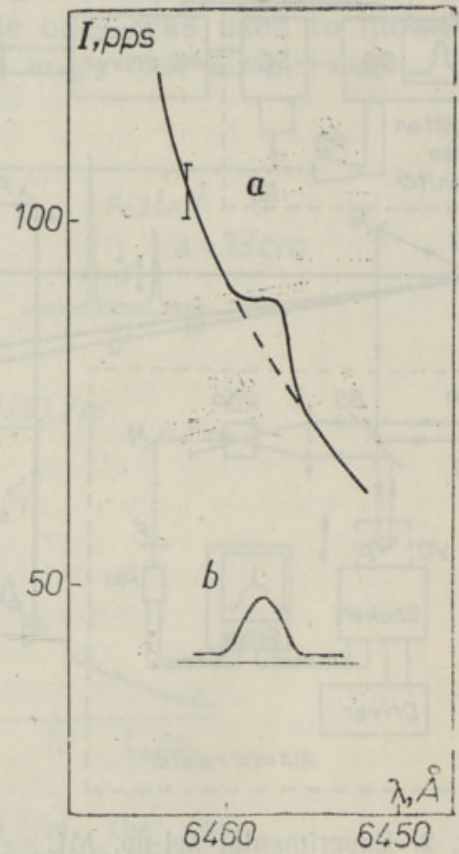
The zeroth-order reflection of
continuous check of the dye laser output. 
expected. The reasons seem to be the poor spatial properties of the beams due to non-top-quality optics and great losses accompanying signal detection. Due to a high background signal level we could not carry out exact decay-time measurement, but a rough quantitative estimation of $T_{2}<100$ ps is not inconsistent with the data of earlier investigations $\left[{ }^{4}\right]$.

Nevertheless our preliminary experiments show that if one reduces the background signal by either using another etalon with a wider free spectral range or by eliminating the krypton stray-light more effectively along with minimizing the losses in the excitation channels, the CARS signal for relaxation time measurement is rather good.

From the above investigations we draw the following conclusions:

1) Synchronously pumped mode-locked CW dye lasers seem rather promising in transient CARS spectroscopy.

2) Introduction of jitter-free pulses from single SP ML CW dye laser in multi-frequency operation is believed to result in further progress in time resolution and to essentially simplify the required equipment.

We would like to thank K. Rebane for supporting and stimulating the present work and K. Timpmann, A. Anijalg and P. Kukk for streak camera measurements.

\section{REFERENCES}

1. Ахм анов С. А., Коротеев Н. И., Успехи физ. наук, 123, вып. 3, 405-471 (1977).

2. Tolles, W. M., Nibler, J. W., McDonald, J. R., Harvey, A. B., Appl. Spectrosc., 31, № 4, 253-271 (1977).

3. H a rvey, A. B., Ni ble r, J. W., Appl. Spectrosc. Rev., 14, № 1, 101-143 (1978).

4. La uberea u, Ä., Ka is er, W., Rev. Mod. Phys., 50, № 3, 607-665 (1978).

5. Le e H. Chi, R i card, D., Appl. Phys. Lett., 32, № 3, 168-171 (1978).

6. Heritage, J. P., Ausschnitt, C. P., Jain, R. K., In: Springer Series in Chemical Physics, 4, Picosecond Phenomena, ed. Shank, C. V., Ippen, E. P., Shapiro, S. L., Springer-Verlag, Berlin-Heidelberg-New York, 1978.

7. Ка а рли Р. К., А а виксо Я.Ю., Вилл А. А. Кукк П. Л., С а а р и П. М., Ф рей 6 е р г А. М., Квант, электроника, 6. № 12, 2630-2633 (1979).

8. A d a m s, M. C., S i b b et t, W., B r a d l e y, D. J., Opt. Commun., 26, № 2, 273276 (1978).

9. Фрейберг А., Р айдару А., Аниялг А., Тимпманн К., Кукк П., С а а р и П., Изв. АН ЭССР, Физ. Матем., 29, № 2, 187-194 (1980).

10. Ахманов А. С., Короте в Н. И., Орлов Р. Ю., Шумай И. Л., Письма в ЖЭТФ, 26, вып. 5, 276-280 (1976).

Academy of Sciences of the Estonian SSR, Institute of Physics

Received

Jan. 4,1980

R. KAARLI, J. AAVIKSOO, A. FREIBERG, P. SAARI

\section{AEGLAHUTUSEGA AKTIIVSE KOMBINATSIOONHAJUMISE SPEKTROSKOOPIA OHE PIKOSEKUNDILISE SUNKROONSELT PUMBATAVA VARVLASERI BAASIL}

Pikosekundiline sünkroonselt pumbatav õhukese etaloniga värvlaser võib töötada nn. multisageduslikus režiimis, s. t. genereerida ühes resonaatoris pikosekundilisi impulsse u̇heaegselt mitmel etalonijoonel. Multisagedusliku impulsi erinevate komponentide väga täpne ajaline kokkulangevus teeb selle laseri perspektiivseks aktiivses neljafootonilises aeglahutusega spektroskoopias.

Kahesageduslikus režiimis töb̆tava sünkroonselt pumbatava oksasiinlaseri rakendamise vōimalusi pikosekundilise eristustäpsusega aktiivses kombinatsioonhajumisspektroskoopias on uuritud vedela lämmastiku näite varal. 
Р. КААРЛИ, Я. ААВИКСОО, А. ФРЕИБЕРГ, П. СААРИ

\section{АКТИВНАЯ СПЕКТРОСКОПИЯ КОМБИНАЦИОННОГО РАССЕЯНИЯ С ВРЕМЕННЫМ РАЗРЕШЕНИЕМ ПРИ ИСПОЛЬЗОВАНИИ ОДНОГО СИНХРОННО НАКАЧИВАЕМОГО ПИКОСЕКУНДНОГО ЛАЗЕРА НА КРАСИТЕЛЕ}

Пикосекундный синхронно накачиваемый лазер на красителе с тонким эталоном способен работать в т. н. многочастотном режиме, т. е. генерировать в одном резонаторе пикосекундный импульс одновременно на нескольких линиях эталона. Очень точное совпадение во времени компонентов многочастотного импульса открывает такому лазеру перспективы в активной четырехфотонной спектроскопии с временным разрешением.

Возможности применения синхронно накачиваемого лазера на оксазиновом красптеле, работающего в режиме двухчастотного импульса в активной спектроскопин комбинационного рассеяния с пикосекундным временным разрешением, исследуются на примере жидкого азота. 